\title{
Research on the Promotion of County Economic Competitiveness in Yunnan Province Under the Background of One Belt and One Road
}

\author{
Ruiting Wang \\ International Business School \\ Yunnan University of Finance and Economics \\ Kunming, China \\ 281302812@qq.com
}

\begin{abstract}
Since the implementation of the "One Belt And One Road" , yunnan has become a new strategic highland, which has a significant and far-reaching impact on the economic takeoff and leapfrog development of yunnan. In yunnan province, county economy plays an indispensable role. County economy is not only the combination of macro-economy and micro-economy, but also the combination of urban and rural areas. Therefore, this paper analyzes the gap between the county economic competitiveness of yunnan province and the top 100 counties, draws lessons from the development advantages of the top $\mathbf{1 0 0}$ counties, and combines the current situation of the county economic development of yunnan province, trying to provide suitable suggestions for improving the county economic competitiveness of yunnan province under the background of One Belt And One Road.
\end{abstract}

Keywords: One Belt and One Road, county economy, competitiveness

\section{INTRODUCTION}

Promulgated by the national development and reform commission (NDRC) in February 2019 , "Policy Measures for Accelerating Construction of Radiation Center in South Asia and Southeast Asia in Yunnan Province" must be made clear that we should make full use of yunnan location, promote the national transport corridor construction with its neighboring countries, build new heights of economiadvantagesc cooperation in the greater Mekong subregion and radiation centers facing south and southeast Asia, which will have a great impact on economic development in yunnan province. Revitalizing the southern silk road is the inevitable choice of China's Indian Ocean strategy and the objective requirement of constructing the bangladesh-china-india-myanmar economic belt.The country's westward opening strategy makes yunnan turn from the end of reform and opening up to the front, which is a new change of geopolitics. Yunnan has a good foundation in the strategy of opening to the west and can play a role in the initiative of "One Belt And One Road".

The Chinese economy has shifted from a stage of highspeed growth to a stage of high-quality development. In terms of achieving high-quality development, promoting coordinated development among regions, building a modernized economic system, and implementing the strategy of rural revitalization, it can be said that the foundation, difficulty and vitality lie in the county. As the basic unit of regional economy,county economic unit plays an important basic function. The full development of county economy is of great significance to the promotion of China's modernization. The backwardness of county economy, on the one hand, is not conducive to improving the backwardness of rural areas, is not conducive to the improvement of farmers' income; On the other hand, it will have a negative impact on the urban construction of the whole city and becomes a bottleneck restricting the economic development of the whole city and even the whole province. County economic development, to a large extent, determines the overall strength of the city's economy and the level of development.Developing county economy can better promote the development of rural economy, promote the modernization of rural economy, and accelerating the development of county economy is the only way to improve China's comprehensive national strength. Therefore, under the background of One Belt And One Road, it is imperative to study how to improve the economic competitiveness of counties in yunnan province.

\section{LITERATURE ANALYSIS}

\section{A. literature review of county economic development and county economic competitiveness}

At present, there have been many scholars carried out to investigate the development of county economy from different angles, some scholars on the influence factors of the county economy development has conducted a series of exploration, such as Liu Lin[1] using multiple regression method, found that the influence factors of east and west county economy in our country is different, the eastern region is mainly due to the credit level; the western region is the industrial structure and urbanization level; Liao yi[2] used thiel index method and gini coefficient method to study the development of county economy in hunan province, revealing that the secondary industry is the most important factor affecting its development, and the industrial structure and its agglomeration effect also have a great impact on the different development of county economy. Feng xinghua[3] analyzed the county economy in the Yangtze river basin and pointed out that geographical location, 
transportation facilities, industrial layout, national policies and other factors were the key factors to promote the change of the county economic layout. Liao jianjiang[4] and Xiong xiaolin [5 believed that the fiscal system of the government directly promoted the development of county economy. Through introducing econometric model, Joseph Berechman[6] pointed out that the role of transportation infrastructure in the development of county economy declined with the lag.

At the same time, many scholars began to explore the differences in the development of county economy in China. For example, Li xiaojian[7] for the first time, added the number-shape analysis into the study of county economic development, pointing out that the research on regional economic development difference in China mainly involves two levels of province and county, and the provincial analysis has some limitations.Zheng yancheng[8], using the theory of economic convergence, pointed out that the imbalance of regional economic development in China basically originated from the imbalance of county economic development, rather than the imbalance of urban economic development. Zhou Yang[9] used EDSA and function method to study the differences in the development of county economy in China, and concluded that the gap in the development of county economy in the eastern region as the hot spot was larger than that in the western region as the cold spot. Zhang xuebo[10], by using the statistical method of spatial clustering, concluded that the lack of funds in the economic development of counties in central and western China was relatively obvious, and inclined to favor the central region of the province where the counties were located, which was more obvious than the more developed eastern region. Zhao yuzhi[11] used the principal component analysis method to reveal the spatial evolution pattern of Jiangxi province, and pointed out that relatively developed counties were generally located in the central region and transportation bases such as waterway hubs. Meng shasha[12] used spatial measurement method to analyze the distribution pattern of county economy in Shandong province, and drew the conclusion that hot counties in the province are all located in the coastal areas of the province. Huang lijuan[13] added synergy theory on the basis of the above research, and combined county economic development with rural transformation. Czako K[14] used the indicator of GDP to reveal the differential pattern of regional economy in doreha since 2000

For the study of county competitiveness, scholars have discussed it from different aspects. Shi Qingyu evaluated the tourism competitiveness of China's land border county rom the natural environment of tourism, tourist resources, regional transportation, tourism, social environment and so on eight aspects, on the basis of the application of clustering analysis to 134 land border tourism competitiveness of the county is divided into resource advantages, the port advantage, location advantage, agglomeration advantages, such as relatively balanced type five types. Zeng jinfa put forward the policy Suggestions of scientifically planning the layout of county competitiveness, scientifically planning the layout of competitiveness projects, and adhering to the scientific development concept of competitiveness to enhance the competitiveness of county economic development. However
Tang shi constructed the evaluation index system of county economic competitiveness with five key factors, namely benefit, foundation, consumption, structure, science and technology, and divided the county economy into five categories: most developed, developed, relatively developed, moderately developed and underdeveloped.

\section{B. literature review of county economic competitiveness in yunnan province}

The discussion on county economic competitiveness in yunnan province was first put forward by scholars du yuyin and li zongjie in 1995. Some scholars from the perspective of industry research in yunnan province, the county economic competitiveness, such as Gong Yingmei ${ }^{[15]}$ to establish a mathematical model for calculation of yunnan county industrialization level of comprehensive index, points out the difference between yunnan province and coastal area economic development mainly embodies in the degree of industrialization, and put forward the need to accelerate the adjustment of economic structure, optimize the industrial structure and so on county economic competitiveness countermeasure; Chen $\mathrm{li}^{[16]}$ adopted deviation share analysis, industrial decomposition and other methods to analyze the impact of industrial structure on the economic development of counties in yunnan province, and proposed that measures to adjust industrial structure could be adopted to enhance their economic competitiveness.

And scholars studied this problem from the angle of regional economy, such as Yang Yanjun[17] in a border county of yunnan province as the object, using the spatial development model, the border county of the three times industrial data and the gross domestic product (GDP) as the main research object, the differences in industrial structure of space research, points out that the secondary industry is inhibiting the development of county economy, and a serious imbalance between the development of the tertiary industry; According to Liu baoqiang[18], initial natural resources, geographical location and regional development policies are the main factors influencing the change of the spatial layout of county economy. Li qingzhe[19] believes that nowadays, the development of county economy in yunnan province is unbalanced, and there are institutional and institutional barriers to the coordinated development between counties. The county economy should also establish a system of regional coordination to achieve hierarchical development

\section{C. literature review}

Existing literature studies the current situation, causes and countermeasures of county economic development and regional economic performance evaluation from different perspectives, and proves fruitful results, which lays a good theoretical foundation for this paper. However, most of the research focuses on the central and eastern regions of China, and there are few relevant discussions in the western regions, especially in yunnan province. Therefore, this paper will analyze the current situation of county economic development in yunnan province, compare it with the national top 100 county economic data, combine the reality of county economic development in yunnan province, draw lessons from the advantages of national top 100 county economic development, 
and put forward targeted Suggestions for improving the county economic competitiveness in yunnan province.

\section{ANALYSIS OF CURRENT SITUATION OF COUNTY ECONOMY DEVELOPMENT IN YUNNAN PROVINCE}

In order to further analyze how yunnan province can improve the competitiveness of county economy under the background of One Belt And One Road, this paper draws the report of "top 100 county economy research in China 2019" from saidi consultant. [6] The ccid county economy research center, adhere to the five development philosophy, follow the scientific, systematic, objective, the basic principles of operation, contrast, establishing a double threshold of RMB 40 billion in GDP and RMB 2 billion in general public budget revenue, the county economy in the development of high quality evaluation index system, including four level indicators, eight secondary indicators, 22 tertiary indicators. More than 200 counties (county-level cities and banners) were selected from 1,879 county-level administrative divisions except municipal districts and forest zones, and China's top 100 counties in 2019 were finally selected.

The top 100 counties are the pacesetting of the development of the counties. This paper starts with the top 100 counties in China in 2019, and queries the GDP of the top 100 counties in 2018 as the auxiliary data to measure the development status of the top 100 counties. Since the statistics bureau of yunnan province has not published the GDP of each county in 2018, this paper has taken the county GDP of yunnan province in 2017 as the standard to measure the economic competitiveness of the top 100 counties in yunnan province. In addition, the GDP of some counties in yunnan province is compared with the GDP of the top 100 counties, so as to analyze the deficiencies of the economic development of the counties in yunnan province, draw lessons from the advantages of the top 100 counties in economic development, and provide corresponding suggestions for improving the economic competitiveness of the counties in yunnan province with the support of the national "One Belt And One Road" strategy. Due to the large list of top 100 counties and counties in yunnan province, this paper selected the representative top 20 and bottom 20 counties of top 100 counties in China in 2019, inquired the GDP values of relevant provinces and 2018, and the top 20 and bottom 20 counties in yunnan province in 2017 .

TABLE I. 2019 PART OF THE NATIONAL TOP 100 COUNTIES AND GDP FIGURES

\begin{tabular}{|c|c|c|c|}
\hline Sort & $\begin{array}{c}\text { County (city, } \\
\text { banner) }\end{array}$ & Provinces & $\begin{array}{c}\text { 2018 GDP } \\
\text { (Hundred million) }\end{array}$ \\
\hline 1 & Kunshan & Jiangsu & 3875 \\
\hline 2 & Jiangyin & Jiangsu & 3806 \\
\hline 3 & Zhangjiagang & Jiangsu & 2720 \\
\hline 4 & Changshu & Jiangsu & 2400 \\
\hline 5 & Jinjiang & Fujian & 2229 \\
\hline 6 & Changsha & Hunan & 1509 \\
\hline 7 & Cixi & Zhejiang & 1737 \\
\hline
\end{tabular}

\begin{tabular}{|c|c|c|c|}
\hline 8 & YIxing & Jiangsu & 1718 \\
\hline 9 & Taicang & Jiangsu & 1330 \\
\hline 10 & Longkou & Shandong & 1238 \\
\hline 11 & Yiwu & Zhejiang & 1248.11 \\
\hline 12 & Jiaozhhou & Shandong & 1211.38 \\
\hline 13 & Rongcheng & Shandong & 1211.24 \\
\hline 14 & Liuyang & Hunan & 1304.99 \\
\hline 15 & Haimen & Jiangsu & 1249 \\
\hline 16 & Leqing & Zhejiang & 1078.52 \\
\hline 17 & Yuyao & Zhejiang & 1105.08 \\
\hline 18 & Fuqing & Fujian & 1102.1 \\
\hline 19 & Danyang & Jiangsu & 1250.25 \\
\hline 20 & Ningxiang & Hunan & 1093.85 \\
\hline 81 & Xiantao & Hubei & 770 \\
\hline 82 & Haiyan & Zhejiang & 503.27 \\
\hline 83 & Gaomi & Shandong & 673.8 \\
\hline 84 & Shuyang & Jiangsu & 825.45 \\
\hline 85 & Xinyi & Jiangsu & 653.32 \\
\hline 86 & Sheyang & Jiangsu & 536.61 \\
\hline 87 & Haicheng & Liaoning & 558.2 \\
\hline 88 & Yongkang & Zhejiang & 557.71 \\
\hline 89 & Jurong & Jiangsu & 571.1 \\
\hline 90 & Qianjiang & Hubei & 755.8 \\
\hline 91 & Liling & Hunan & 663.9 \\
\hline 92 & Zhuanghe & Liaoning & 600.7 \\
\hline 93 & Jiyuan & Henan & 641.84 \\
\hline 94 & Dengfeng & Henan & 703.03 \\
\hline 95 & Panzhou & Guizhou & 596.44 \\
\hline 96 & Zaoyang & Hubei & 656 \\
\hline 97 & Kuerle & Xinjiang & 616.14 \\
\hline 98 & Gaoyou & Jiangsu & 660 \\
\hline 99 & Ruzhou & Henan & 468.02 \\
\hline 100 & Changji & Xinjiang & 398 \\
\hline
\end{tabular}

As can be seen from table I, the regional development of the top 100 counties is extremely unbalanced. The eastern region of the top 100 counties accounted for 71 seats, the central region accounted for 19 seats, the western region accounted for 7 seats and the northeast region accounted for 3 seats. Compared with 2018, the eastern region lost three seats, the central region gained three seats, the western region lost one seat and the northeast region gained one seat. The rise of the central region and the revitalization and development of the northeast have yielded initial results. The counties of heilongjiang, jilin, shanxi, gansu, qinghai, ningxia, sichuan, 
yunnan, chongqing, xizang, guangxi and hainan were not among the top 100 .

TABLE II. COUNTY GDP RANKING OF YUNNAN PROVINCE IN 2017

\begin{tabular}{|c|c|c|c|c|c|}
\hline Sort & $\begin{array}{l}\text { County } \\
\text { (city, } \\
\text { banner) }\end{array}$ & $\begin{array}{c}\text { 2017 GDP } \\
\text { (Hundred } \\
\text { million) }\end{array}$ & Sort & $\begin{array}{c}\text { County } \\
\text { (city, } \\
\text { banner) }\end{array}$ & $\begin{array}{c}\text { 2017 GDP } \\
\text { (Hundred } \\
\text { million) }\end{array}$ \\
\hline 1 & Mile & 287.65 & 82 & Honghe & 39.41 \\
\hline 2 & Xuanwei & 272.8 & 83 & Huaping & 38.05 \\
\hline 3 & Gejiu & 243.48 & 84 & XIchou & 37.68 \\
\hline 4 & Wenshan & 228.59 & 85 & Shuangbai & 37.62 \\
\hline 5 & Mengzi & 190.96 & 86 & Yongren & 36.52 \\
\hline 6 & Kaiyuan & 185.89 & 87 & Ninglang & 36.29 \\
\hline 7 & Huize & 180.25 & 89 & Weixin & 36.07 \\
\hline 8 & Luoping & 169.88 & 90 & Lvchun & 33.53 \\
\hline 9 & Luliang & 168.03 & 91 & Daguan & 32.99 \\
\hline 10 & Jianshui & 152.13 & 92 & Pingbian & 32.31 \\
\hline 11 & Fuyuan & 147.77 & 93 & Deqin & 31.11 \\
\hline 12 & Luquan & 141.89 & 94 & Jianchuan & 30.79 \\
\hline 13 & Xinping & 139.68 & 95 & Menglian & 28.77 \\
\hline 14 & Xiangyun & 138.64 & 96 & Jiangcheng & 28.29 \\
\hline 15 & Yanshan & 121.55 & 97 & Yangbi & 22.72 \\
\hline 16 & Xianggelila & 120.64 & 98 & Suijiang & 22.61 \\
\hline 17 & Shizong & 118.14 & 99 & Lianghe & 21.46 \\
\hline 18 & Zhenxiong & 113.1 & 100 & Fugong & 15.05 \\
\hline 19 & Tonghai & 112.38 & 101 & Ximeng & 13.57 \\
\hline 20 & Guangnan & 109.54 & 102 & Ghongshan & 12.64 \\
\hline
\end{tabular}

As can be seen from table II, the economic development level of each county in yunnan province is extremely uneven. On the whole, the GDP of each county in yunnan province is relatively low, and there is still a large space for development. In terms of geographical location, counties with strong economic competitiveness in yunnan province are mostly concentrated in the central yunnan economic belt, which relies on the coordinated development of the economic belt. The lower ranked counties are mostly located near the border between China and south and southeast Asia, or due to inconvenient transportation or remote geographical location and lack of pillar industries, resulting in low competitiveness of local economy.

From table I and table II, it can be seen from the distribution characteristics that the top 100 counties are still unevenly distributed and dominated by the eastern part of China. Strong provinces and strong counties are a major feature of the pattern of top 100 counties. Economically developed counties are mostly located along the eastern seaboard. Among the major counties in the east, the top 100 counties have higher population density and stronger population concentration. From the above table, we can also see that, compared with the top 100 counties in China, the overall level of economic competitiveness of counties in yunnan province is relatively low. Among them, there are 3 hundred billion counties in the top 100 counties, and the lowest ranked Changji county has a GDP of nearly 40 billion. In the counties of yunnan province, Maitreya, the city with the highest GDP, only has 28.765 billion, which is still far from 40 billion. Compared with the kunshan city in jiangsu province which has the highest GDP value in the top 100 counties, gongshan county of the lowest GDP value in yunnan province, the difference between the two cities' GDP is 306 times, The above data is sufficient to prove that the overall competitiveness level of county economy in yunnan province is low.

Looking at the development process of the top 100 counties, we find that the top 100 counties have both the support of industrial industry and the strong pull of service industry. The focus of county economic development lies in industrial transformation and upgrading. In this regard, the top 100 counties also have certain experience and advantages. The primary driving force for the development of the top 100 counties is the secondary industry. In 2018, the added value of the secondary industry reached 5.03 trillion yuan, accounting for 52.4 percent, 11.7 percentage points higher than the national average. At the same time, most of the top 100 counties have the characteristics of urbanization, are still at the level of rapid urbanization, have the advantages of land, labor costs. However, in yunnan province, the level of urbanization in the county area is relatively low, and there is a lack of skilled talents and the loss of labor force. In addition, yunnan province is located in the southwest border of China, with mountainous areas, backward infrastructure and inconvenient transportation, which leads to the low level of industrialization and the lack of economic competitiveness.

\section{SUGGESTION}

Through the above-mentioned analysis, we can see the county of yunnan province overall competitiveness level is low, many problems exist in the process of development, this article summarizes the top county development advantages, considering the reality of county economy development in yunnan province, and combined with the implementation of the strategy of "area", from the following aspects for yunnan province county territory economy development puts forward pertinent suggestions, expected to promote the competitiveness of the county economy in yunnan province.

\section{A. Focus on local characteristics}

According to their own location, natural and resource endowment conditions, according to local conditions, classification and guidance, determine the leading industries, implement key development, cultivate local characteristics in resource advantages, select advantageous brands in traditional products, build characteristic industries and famous brand products.Yunnan province is rich in tourism resources and located at the southern gate of China with beautiful scenery. Therefore, it advocates one county and one industry, one township and one product to vigorously develop tourism and cultivate and develop characteristic economy[9]. 


\section{B. Promote urbanization and take the road of a new type of industrialization}

Urbanization can be said to be the development direction of county economy, and industrialization is the core power to enhance the competitiveness of county economy.Vigorously promote industrialization, urbanization and agricultural modernization is the only way to enhance the competitiveness of county economy, its core is industrialization[10]. The development experience of advanced counties tells us that the industrial concentration area is an important carrier for promoting industrialization and urbanization, the most dynamic and potential new space in the county economy, and the basic platform for attracting investment and project construction. The focus of county economy is concentrated area, development potential is concentrated area, create brilliant rely on concentrated area. Wherever the county economy develops well, industrialization and urbanization are also in the forefront, accelerating the process of urbanization and striving to promote urbanization. We will continue to do a good job in the planning, construction and management of county towns and key towns.

\section{Make full use of national policy support}

Make full use of the support of national "One Belt And One Road" policy and give full play to the geographical advantages of yunnan. Promote the construction of international transport channels with neighboring countries, and actively integrate into the construction of One Belt And One Road.Promoting the vigorous development of border trade and tourism, building a new height of greater Mekong subregion economic cooperation, building it into a radiation center facing south and southeast Asia, and enhancing the overall economic competitiveness of counties in yunnan province.

\section{Build the atmosphere that develops county area economy}

To promote the development of county economy, as the daily work of the provincial party committee, the provincial government and its departments, give substantial support to the county economy in terms of funds, projects, talents and policies[11]. In the policy support must provide the necessary preferential treatment, increases the investor's confidence and the enthusiasm; In terms of government services, we must be resolute in upholding integrity and efficiency, and transform our service concepts and methods.In particular, we should speed up the transformation of the functions of the provincial departments, simplify the examination and approval procedures, improve the efficiency, and truly proceed from the actual situation of the county economy to develop quality services.

\section{E. County levels will be given more autonomy in development}

In accordance with the principle that powers and responsibilities should be unified when they can be delegated, and with reference to the standard for the top 100 counties to expand their powers, all counties and cities should reasonably expand their powers of economic management, grant countylevel governments greater autonomy and decision-making power in development, and enhance their economic control ability in coordinating urban and rural development.

\section{CONCLUSIONS AND PROSPECTS}

This paper compares the county economic competitiveness of yunnan province with that of the top 100 counties, combines the implementation of the current One Belt And One Road policy, and draws lessons from the development advantages of the top 100 counties, and puts forward corresponding suggestions for improving the county economic competitiveness of yunnan province. However, due to the limited academic and research level of individuals and the lack of more data support, the research methods still need to be supplemented and improved. We can also analyze the local advantageous industries more concretely and put forward some suggestions for the economic development of each county in yunnan province.

\section{ACKNOWLEDGMENT}

Funding for research was provided by National Natural Science Foundation of China under grants 71763028. Thanks to the scholars involved in this paper, this paper cites the research literature of several scholars, without the help and inspiration of the research results of scholars, I will be very difficult to complete the writing of this paper. Thanks $s$ to my teacher - zhang honglie teacher, in the process of my writing paper has been constantly guiding me. I would like to thank my classmates and friends for their kind help in my writing. Due to my limited academic level, there are inevitably some shortcomings in the paper, please kindly criticize and correct me.

\section{REFERENCES}

[1] Liu Lin, Tang lian, Qin wanshun. Factors influencing the uneven development of county economy: a comparison between east and west [J]. Economic science,2010(04):122-128.

[2] Liao yi, Zhou chuan-invention, Tang yu-feng. Empirical study on the change of regional economic differences in hunan county [J]. Economic geography, 2014,34(02):35-41.

[3] Feng xinghua, Zhong yexi, Chen Lin, Fu yu. Analysis on the evolution of county economic spatial pattern in the Yangtze river economic belt $[\mathrm{J}]$ Economic geography,2016,36(06):18-25.

[4] Liao jianjiang, Zhu jianbing. Empirical analysis on the impact of the financial system reform of "provincial direct supervision of counties" in hunan on the economic development of counties $[\mathrm{J}]$. Economic geography,2017,37(04):52-57+116.

[5] Xiong xiaolin, Li tuo. Basic public services, fiscal decentralization and county economic development [J]. Statistical research,2018,35(02):6674.

[6] Joseph Berechman, Dilruba Ozmen, Kaan Ozbay. The Empirical analysis of transportation investment and economic development at the state, county and municipality levels [J]. Transportation, 2006, Vol. 33 (6) : 537-551.

[7] Li xiao-jian, Qiao jia-jun. Spatial analysis of inter-county economic differences in China in the 1990s [J]. Acta geographica sinica,2001(02):136-145.

[8] [8]Zheng yancheng, Lu deyin. Analysis on the explanatory power of unbalanced county economic development on regional disparity [J]. Financial and economic research,2004(07):121-129.

[9] Zhou Yang, Li ning, Wu wenxiang, Wu jidong. Evolution of spatiotemporal pattern of county economic development in China from 1982 to 2010 [J]. Progress in geographical science,2014,33(01):102-113.

[10] Zhang xue-bo, Yang chengfeng, Song jin-ping, Li wei. Evolution of spatial pattern of economic difference in China's interprovincial marginal counties [J]. Economic geography,2015,35(07):30-38. 
[11] Zhao yuzhi, Dong ping. Analysis of county economic difference characteristics and its causes in jiangxi province [J]. Human geography,2012,27(01):87-91.

[12] Meng shasha, Zhang xiaoqing, Zhang yuze, Huang caihong, Yin shou, bai Chen. Study on spatial pattern evolution and driving mechanism of county economy in shandong province $[\mathrm{J}]$. East China economic management,2017,31(12):27-34

[13] Huang lijuan, Ma xiaodong. Analysis of spatial synergy between county economy and rural transformation and development in jiangsu province [J]. Economic geography,2018,38(06):151-159.

[14] Czako K,Fekete D,Poreisze v.omic Differences of COUlltries by the River Danube[J].Journal of Procedia Economic and finance,2014(9):163-175.

[15] Gong yingmei, Gu youjin. Evaluation and countermeasures on the development level of new industrialization of county economy in yunnan province $[\mathrm{J}]$. Exploration of economic problems,2009(02):179184.
[16] Chen li, Zhu xigang, Li xiaohu. A study on county economic differences in yunnan province from the perspective of industrial structure [J]. Geographic sciences,2016,36(03):384-392.

[17] Yang yanjun, Luo huazong, Liu dejiang, Huang li. Analysis of economic spatial difference in border counties of yunnan province based on shiftshare spatial expansion model $[\mathrm{J}]$. World geography research,2012,21(04):48-56

[18] Liu bao-qiang, Xiong li-ran, Jiang mei-ying, Zhang lei. Analysis of spatial pattern evolution of county economy in yunnan border region [J]. Regional research and development,2017,36(03):29-35.

[19] [19]Li qingzhen. Research on county economic development in yunnan from the perspective of regional economy $[\mathrm{J}]$. Exploration of economic issues,2017(05):95-100. 